\title{
Peranan Orang Tua Siswa dalam Penerapan Nilai-Nilai Pendidikan Agama Islam pada Masa Panemi Covid-19 (Studi deskriptif kualitatif di SDN Cariu 01 Kabupaten Bogor)
}

\author{
Ani Muflikah ${ }^{1 *}$, , E. Tajuddin Noor ${ }^{2}$, Taufik Mustofa ${ }^{3}$ \\ 1, 2, 3 Prodi Pendidikan Agama Islam FAI UNSIKA Karawang
}

* Corresponding Author. E-mail: animuflikah78@gmail.com

\begin{tabular}{|l|l|l|}
\hline Receive: 13/07/2021 & Accepted: 23/08/2021 & Published: 04/10/2021
\end{tabular}

\begin{abstract}
Abstrak
Peranan orang tua merupakan kegiatan inti dalam sebuah pembiasaan kegiatan pendidikan di rumah. Peranan orang tua dilihat dari aspek nilai-nilai pendidikan agama islam yang tercermin dalam tingkah prilaku, akhlakul karmah dan keimanan kepada Allah SWT. Pada saat pandemi covid-19 saat ini, orang tua kan berperan ekstra karena semua pembelajaran di sekolah menjadi di rumahkan. Penelitian ini bertujuan untuk mengetahui: (1) Peranan orang tua dalam penerapan nilai-nilai pendidikan agama islam (2) Bentuk peranan orang tua dalam penerapan nilai-nilai pendidikan agama islam. Hasil penelitian ini menunjukan bahwa peranan orang tua dalam penerapan nilai-nilai pendidikan agama islam masih ditemukan bahwa banyak orang tua yang belum paham betuk peranannya terhadap pendidikan anak, juga dalam penerapan nilai-nilai pendidikan agama islam terhadap anaknya.

Kata kunci: Peranan orang tua siswa dalam penerapan nilai-nilai pendidikan agama islam
\end{abstract}

\begin{abstract}
The role of parents is a core activity in a habituation of educational activities at home. the role of parents is seen from the aspect of the values of Islamic religious education which is reflected in behavior, morality, karma and faith in Allah SWT. During the current covid-19 pandemic, parents have an extra role because all learning at school is at home. This study aims to determine: (1) The role of parents in the application of Islamic religious education values (2) The form of the role of parents in the application of Islamic religious education values. The results of this study indicate that the role of parents in the application of Islamic religious education values is still found that many parents do not understand the form of their role in children's education, as well as in the application of Islamic religious education values to their children.
\end{abstract}

Keywords: The role of parents in the application of Islamic religious education values

\section{Pendahuluan}

Peranan orang tua terintegrasi dalam proses terjadinya pendidikan. Dalam menunjang pendidikan yang berhasil, orang tua menjadi tolak ukur, contoh dan pembimbing dalam proses terjadiya pendidikan internal. Peranan orang tua dalam pendidikan mempunyai poin penting, karena dengan adanya peranan orang tua di dalam proses pendidikan akan sangat membantu bagi pembelajaran anak. Dukungan orang tua mewujudkan keberhasilan anak. Orang tua adalah pendidikan pertama bagi anak-anaknya, maka sebagai orang tua harus berusaha untuk memberikan fasilitas dengan menyekolahkan anak sampai ke jenjang pendidikan paling tinggi. Degan cara ini, anak akan lebih terarah, mendapatkan ilmu pengetahuan yang cukup yang akan menjadikan anak mandiri secara finansial nantinya.
Tak hanya orang tua, namun keluarga pun dapat andil dalam hal ini. Keluarga merupakan lingkungan pendidikan yang utama dan pertama yang dialami oleh anak, jika pola pendidikan dalam lingkungan keluarga dihiasi oleh ajaran-ajaran agama dengan sendirinya kodidi ini akan terdampak terhadap prilaku anak. Hal ini dikarenakan orang tua, keluarga memberikan contoh atau keteladanan yang baik kepada mereka. Di samping itu, ada pula orang tua yang taat beragama, namun sulit mengajak anakanaknya untuk beribadah. pengaruh lingkungan yang serba material dan glamoran, telah menyebabkan keluarga-keluarga muslim muslimah menghadapi kendala untuk beribadah seuai dengan tuntutan agamanya.

Pada masa pandemi covid-19 seperti saat ini, peranan orang tua akan meentukan proses pembelajaran anak. karena dalam masa pandemi ini, 
Jurnal Edumaspul, 5 (2), Year 2021- 536

(Ani Muflikah , , E. Tajuddin Noor, Taufik Mustofa)

semua pembelajaran yag seharusnya dilakukan di sekolah menjadi di rumahkan. Pada sistem pembelajaran jarak jauh ini, teknologi akan mendominasi dalam proses pembelajaran berlangsung. Maka dari itu, orang tua menjadi peran penting dalam proses pembelajaran di rumah. Orang tua harus menunjang anak- anaknya dalam pengimplementasian segala mata pelajaran yang telah diberikan guru secara online. Dalam hal ini, pendidikan agama islam menjadi salah satu pembelajaran yang harus diberikan pemahaman dan pelaksanaan yang benar.

Nilai-nilai pendidikan agama islam adalah pendidikan yang memberikan pengetahuan, membentuk sikap, kepribadian dan keterampilan peserta didik dalam mengamalkan ajaran agamannya. Dalam membentuk sikap yang agamis, diperlukan adanya konsistensi antara islam, iman dan ihsan. Dengan adanya ketiga pokok ini, seorang muslim bisa menjadi muslim yang seutuhnya dan mencapai derajat mukmin dan muhsin. Sikap agamis ialah integrasi secara kompleks antara pengetahuan agama, perasaan agama dan tindak keagamaan dalam diri seseorang. Pendidikan akhlak ialah ilmu yang dipelajari dari keseharian keluarga, dengan contoh dan teladan dari orang tua. Prilaku dan sopan santun anak akan tercermin pada hubungan dan pergaulan anatara ibu dan bapak, perlakuan orang tua terhadap anak-anak meraka, dan perlakuan oarang tua terhadap orang lain di dalam lingkungan keluarga dan masyarakat.

Aspek nilai-nilai agama islam pada initinya dapat dibedakan menjadi tiga jenis yaitu, nilai-nilai aqidah, nilai-nilai ibadah, dan nilai-nilai akhlak. Nilainilai aqidah mengajarkan manusia untuk percaya akan adanya Allah Ynag Maha Esa dan Maha Kuasa sebagai Sang Pencipta Alam Semesta yang akan senantiasa mengawasi dan memperhitungkan segala perbuatan manusia di dunia. Dengan merasa sepenuh hati bahwa Allah itu ada dan Maha Kuasa, maka manusia akan lebih taat dalam menjalankan sesuatu yang telah diperintahkan oleh Allah dan takut untuk berbuat dhalim atau kerusakan dimuka bumi ini. Nilai-nilai ibadah mengajarkan pada setiap manusia agar dalam setiap perbuatannya senantiasa dilandasi hati yang ikhlas guna mendapatkan ridho Allah. Pengamalan konsep nilai-nilai ibadah akan melahirkan manusiamanusia yang adil, jujur, dan suka membantu sesamanya. Selanjunya yang terakhir nilai-nilai ahklak mengajarkan pada manusia unatuk bersikap dan berprilaku yang baik sesuai norma atau adab yang benar dan baik, sehingga akan membawa kehidupan manusia yang tentram, damai, harmonis dan seimbang. Dengan demikian jelas bahwa nilai-nilai ajaran agama islam merupakan nilai-nilai yang akan mampu membawa manusia kepada kebahagiaan, kesejahteraan, dan keselamatan manusia baik dalam kehidupan manusia di dunia maupun kehidupan di akhirat kelak.

\section{METODE PENELITIAN}

Metode dan pendekatan penelitian yang digunakan adalah metode kualitatif. Dikarenakan dalam penelitian ini, berusaha menelaah fenomena sosial dalam susunan yang berlangsung secara wajar atau ilmiah, bukan dalam kondisi yang terkendali atau laboratoris. Metode kualitatif ini sering disebut sebagai penelitiannaturalistic karena penelitian yang dilakukan dalam kondisi yang alami. Pendekatan kualitatif merupakan prosedur penelitian yang menghasilkan data deskriptif berupa data-data tertulis maupun lisan dari orang-orang dan prilaku yang diamati.

Dengan pendekatan kualitatif, penulis dapat terjun langsung untuk mengadakan wawancara dengan responden, observasi, bahkan penulis turut serta dalam proses, sehingga penulis dapat mengetahui secara mendalam mengenai subtansi yang diteliti. Dalam pendekatan ini, tidak ada alat penelitian secara baku karena alat pemenelitian diseseuaikan dengan keadaan dan yang paling pending peneliti sendiri sebagai instrumen kunci atau utama.

Metode yang akan digunakan dalam penelitian kualitatif ini adalah, metode analisis deskriptif kualitatif. Dengan menggunakan metode ini, peneliti akan mengumpulkan data yang diperoleh kemudian ditafsirkan. Data yang akan dicara yaitu mengenai peranan orang tua dan pengimplementasian nilai-nilai pendidikan agama islam.

\section{HASIL PEMBAHASAN}

Berdasarkan hasil dari observasi, wawancara dan teknik pengumpulan data tentang adanya "peranan orang tua dalam penerapan nilai-nilai pendidikan agama islam pada masa pandemi" ini menunjukkan bahwa adanya peranan penting orang tua dan bentuk penerapan nilai-nilai pendidikan agama islam dalam keluarga di masa pandemi covid-19. Dari hasil data temuan yang didapat, bahwa adanya peranan orang tua dalam penerapan nilai-nilai agama islam bahwa setiap orang tua pada dasarnya mengharapkan anaknya memiliki kepribadian yang bai, berudi pekerti luhur, berpendidikan, bermoral dan berakhlakul karimah.

Para orang tua siswa yang terdapat dari kelas IV A SDN CARIU 01, menunjukan hasil adanya peranan orang tua dalam penerapan nilai-nilai pendidikan agama islam pada amsa pandemi. para orang tua di kelas IV A ini menjadi pembimbing terbaik dengan menyediakan fasiitas yang menunjang untuk terlaksananya pembelajaran jarak jauh. mencadi contoh dan pelopor utama di setiap pembelajaran. Para ibu dan bapak bekerja sama dengan semua anggota keluarga agar saling membantu dan tetap menjadi contoh bagi anak-anaknya. bentuk dari nilainilai pendidikan agama silam ini ialah, berbudi pekerti luhur, berakhlakul karimah, juga disiplin diri.

Bentuk penerapan nilai-nilai pendidikan agama islam yang telah orang tua terapkan kepada anaknya melalui contoh dalam tindakan, pengetahuan tentang 
Jurnal Edumaspul, 5 (2), Year 2021- 537

(Ani Muflikah , , E. Tajuddin Noor, Taufik Mustofa)

agama, berupa ibadah wajib dan sunah juga hal-hal yang diperbolehkan dan yang diharamkan. Orang tua mempunyai cara-cara yag berbeda antara satu dan lainnya dalam penerapan nilai-nilai pendidikan agama islam pada anaknya, rata-rata dari orang tua siswa ini mewajibkan anak-anaknya untuk mengikuti pembelajaran agama secara khusus seperti mengaji dan pesantren. Dalam penerapan nilai-nilai pendidikan agama islam ini, orang tua seringkali mendapatkan hambatan, baik dari anak itu sendiri maupun dari lingkungan sekitar.

\section{Konsep Peranan Orang tua}

Peranan adalah perilaku sosial seseorang yang di tinjau dari segi struktur-struktur sosial yang merumuskan bagi dia siapa dia, karena strukturstruktur sosial menentukan peranan dan pola perilaku yang tetap, dan mengenakan kepada hal-hal yang diharapkan oleh masyarakat, ketunggalan seseorang melenyap di balik peranan yang telah di lembagakan oleh masyarakat, pelembagaan itu di adakan demi suatu kepaduann agar peranan-peranan yang resmi itu dipakai sebagai sistem sosial yang mengintegrasikan orang kedalam kesatuan sosial.

Orangtua adalah komponen keluarga yang terdiri dari ayah dan ibu, yang secara sadar mendidik anak-anaknya untuk mencapai kedewasaan. Berdasarkan pengertian keduanya di atas, dapat diambil pengertian bahwa peranan orangtua adalah hak dan kewajiabn ayah dan ibu yang harus dilakukan sesuai dengan fungsi dan kedudukannya sebagai keluarga di dalam masyarakat dalam mendidik anakanaknya untuk mencapai kedewasaan. Orang tua berperan dalam Pendidikan anak untuk menjadikan Generasi muda berkedudukan. Menurut Abu Ahmadi dalam Hendi Suhendi dan Ramdani Wahtu (2001:4).

Tidak hanya orang tua yang berperan dalam pendidikan anak, namun keluarga pun mempunyai andil yang sama. Keluarga adalah kelompok yang berdasarkan tali sanak-saudara, terdiri dari sekelompok orang yang mempunyai hubungan darah, tali perkawiana atau adopsi dan yang hidup bersamasama dalam periode yang tidak terbatas. Keluarga adalah wadah yang sangat penting diantara individu dan grup, dan merupakan kelompok sosial yang pertama diman anak-anak menjadi anggotanya. Dan kelargalah sudah barang tentu yag petama-tama pula menjadi tempat mengadakan kontak dan yang pertama pula untuk mengadakan sosialisasi kehidupan anak-anak. Ayah ibu dan saudara-saudaranya serta keluarganya yang lain adalah orang-orang pertama yang dimana anak-anak mengadakan kontak, dan yang pertama juga untuk mengajarkan anak-anak itu sebagaimana ia hidup dengan orang lain. Sampai anakanak memasuki usia sekolah,mereka itu menghabiskan seluruh waktunya di dalam unit keluarga. (Abu Ahmad, 1991: 108).

Orang tua adalah komponen keluarga yang terdiri dari ayah dan ibu, yang secara sadar mendidik anak-anaknya untuk mencapai kedewasaan.
Berdasarkan pengertian keduanya di atas, dapat diambil pengertian bahwa peranan orangtua adalah hak dan kewajiabn ayah dan ibu yang harus dilakukan sesuai dengan fungsi dan kedudukannya sebagai keluarga di dalam masyarakat dalam mendidik anakanaknya untuk mencapai kedewasaan. Orang tua berperan dalam Pendidikan anak untuk menjadikan Generasi muda berkedudukan. Menurut Abu Ahmadi dalam Hendi Suhendi dan Ramdani Wahtu (2001:4).

Tidak hanya orang tua yang mempunyai peran dalam pendidikan anaknya, namun guru pun mempunyai peranan yang berbeda. Peranan guru adalah terciptanya serangkai tingkah laku yang saling berkaitan yang dilakukan dalam situasi tertentu serta berhubungan dengan kemajuan perubahan tingkah laku dan perubahan siswa yang menajdi tujuannya. (Uzer, 2017: 4)

Peanan guru dalam hubungannya dengan murid adalah usaha guru mendik dan mnegajar anak dalam kelas guru harus sangup menunjukan kewibawaan atau otoritasnya, artinya ia harus mampu mengendalikan, mengatur, dan mengontrol kelakuan anak. Kalau perlu ia dapat menggunkaan kekuasaanya untuk memaksa anak mengajar, melakukan tugasnya, atau mematui peraturan. Dengan kewibawaan ia menegakkan disiplin demi kelancaran ketertiaban proses belajara mengajar. (Nasutio, 2011: 92).Dalam hal ini, masyarakat pun mempunyai andil dalam peranannya ialah sebagai pengaruh masyarakat terhadap pendidikan sangat kuat, dan berpengaruh kepada para individu yang ada dalam lingkungan sekolah. Lingkungan sekolah merupakan masyarakat kompleks, terdiri dari berbagai macam tingkatan masyarakat yang saling melengkapi dan bersifat unik sebagai akibat latar belakang dimensi budaya yang beraneka ragam. Masyarakat yang kompleks terdiri dari kelompok-kelompok kecil dengan ciri-ciri kolektif yang dimilikinya, mempunyai peranan yang berbeda tarhadap pendidikan anak. Masyarakat bisa juga menjadi pendorong dalam hal pendidikan, namun bisa juga menjadi penghambat, yang bisa merusak generasi dan menyebabkan banyak kerugian lainnya. Sepertihalnya pergaulan bebas, kenakalan remaja, tingkah laku masyarakat yang kurang baik, dan lain sebagainya. Masyarakat dipandang sebagai laboratorium, dimana anak belajar, menyelidiki dan turut serta dalam usaha-usaha masyarakat yang mengandung unsur pendidikan. (Abu Ahmad, 1991: 133)

Bermacam ragam peranan yang yang memiliki andil dalam pendidikan anak tentu sangatlah berpengaruh begi perkembangan sifat dan kebiasaan-kebiasaan anak. Dimulai dari peranan orang tua yang mengacu pada pendidikan informalnya, yang telah terbentuk dari sejak lahir hingga usia siap sekolah juga berlangsung sampai dewasa. Peranan guru yang mengacu pada pendidikan formal yang mengajarkan banya sekali ilmu-ilmu pengetahuan. Peranan masyarakat yang 
tentu menjadi pendidikan eksternal, yang memiliki andil dalam pembiasaan anak dalam bermasyarakat dan bersosialsasi.

\section{Pendidikan Keimanan}

Pendidikan keimanan adalah sinergi berbagai unsur aktivisan pedagogis: pengaitan anak-anak dengan dasar-dasar keimanan,pengakrabannya dengan rukun-rukun islam, dan pembelajarannya tenang perinsip-prinsip syariat islam, pendidikan karakter dan insting anak yang tumbuh berkembang, pengarahan prilaku mereka sesuai dengan fondasi nilai, prinsip-prinsip, dan norma-norma etik yang bersumber dari keimanan yang benar kepada Allah SWT, malaikat, kitab-kitab, par rasul, hari alhir, dan qadha-Nya, yang baik ataupun buruk. (Hannan 2013: 1).

Pendidikan keimanan termasuk salah satu jenis pendidikan terpenting yang mempunyai pengaruh yang sangat besar dalam kepribadian seseorang yang mebuatya menjadi orang yang cenderung kepada kebaikan, menghias diri dengan sifat-sifat terpuji dan selalu membiasakan diri dengan akhlakul karimah.

Pendidikan keimanan menjadi kewajiban orang tua terhadap anak-anak mereka dalam setiap fase pertumbuhan anak, tentusaja dengan memperhatikan metodologi pelaksanaanya. (Hannan, 2013: 2-3).

Sudah selayaknya sebagai orang tua memanfaatkan setiap kesempatan berharga yang tersedia untuk menambah dan membekali anak-anak mereka dengan tindakan-tindakan yang memperkuat aspek keimanan dan akidah.

1) Pokok-Pokok Pendidikan Keimanan Bagi Anak

a) Mentalkin Dengan Kalimat Tauhid

Salah satu hal terpenting ayang harus diupayakan kedua orang tua muslim adalah mengajar dan melatih anak-anak mereka untuk mengucapkan dua kalimat syahadat, sambil terus menerus mengingatkan mereka agar mengucapkan kalimat tersebut setiap saat, sebab kalimat syahadat mengandung unsur pembaruan dan peremajaan keimanan.

Ibnu Qayyim Al-Jauziyah mengatakan: Jika anak-anak sudah menginjak usia bicara, maka latihlah mereka degan kalimat la ilahaillallah Muhammadur Rasulullah. Usahakan agar hal yang pertama kali terdengar di telinga mereka, adalah pengenalan Allah SWT dan pengesaan-Nya, disertai penegasan bahwa Dia berada di atas arsyNya, melihat dan mendengar mereka, dan dia bersama mereka di manapun mereka berada.

b) Mengajarkan dan Mengakrabkan Anak dengan Alquran

Hal yang harus disadari oleh kedua orang tua, bahwa kesalehan generasi akhir umat itu ditentukan oleh komitmen mereka untuk menyamai kesalehan generasi pertamma islam. Mengingat kesalehan dan kejayaan generasi pertama umat itu diraih dengan membaca, mengamalkan dan mempraktikan A-quran, serta dengan menjadikan islam sebagai paradikma, pemikiran, prilaku, dan aksi, maka generasi akhir umat pun tidak akan mencapai tingkat kesalehan dan kemuliaan kevuali naka-anak mereka dididik untuk memahami dan mengamalkan Alquran, membaca dan menafsirkannya.

Sudah seyogianya bagi orang tua agar giat mengajarkan Alquran pada anak-anak mereka, baik laiki-laki maupun perempuan, sejak dini. Tujuannya adalah agar mereka dapat melangkah pada keyakinan bahwa Allah SWT adalah Tuhan mereka, bahwa ini Alquran adalah Kalam-Nya, sehingga ruh Alquran mengalir didalam hati mereka, cahayanya memancar didalam pemikiran, pemahaman, dan indra mereka.

Dalam kesempatan ini, orang tua juga perlu menjelaskan beberapa etika orang yag mempelajari dan menghafal Alquran kepada anak-anak ialah sebagai berikut:

a) Niat mempelajarai Alquran adalah karena Allah SWT, beretika sesuai etika-Nya, menjalankan perintah-Nya, menjauhi larangan-Nya dan berwudhu sebeluh menyentuh mushaf.

b) Khusyu, merenungkan ayat-ayat yang dibaca, dan membayangkan dirinya bahwa dia sedang mermunajat kepada Allah.

c) Tartil (membaca dengan jelas dan bagus) sambil memperindah suara saat membaca Alquran.

d) Ketika ia membaca ayat tasbih, sebaiknya ia ikut tasbih. Ketika membaca ayat yang berisi tentang doa dan istigfar, sebaiknya ia ikut berdoa dan beristigfar. Ketika membaca ayat anjuran dan harapan, sebaiknya ia meminta. Ketika membaca ayat ancaman dan menakut-nakuti, sebaiknya ia memohon perlindungan. Hal itu bisa dilakukan dengan lisan maupun hanya cukup di dalam hati.

e) Menangis ketika membaca Alquran.

f) Memperhatikan dan mendengarkan dengan baik.

g) Khusyu dan merasa takut kepada Allah.

h) Menguatkan Aspek-aspek Akidah yang Berpengaruh pada Hati Anak.

Pada fase akhir kanak-kanank yaitu pada usia sembilan sampai dua belas tahun, pemikiran anak biasanya mengalami peningkatan, pengetahuannya sudah mulai beragam, dan wawasannya meluas. Pada usia tersebut anak merupakan makhluk yang paling luhur, paling jernih hati dan tubuhnya. Ia belum terkena virus-virus dengki, dendam dan tamak, serta belum dikuasai syahwat dan hawa nafsu. Karena itu jika ia diarahkan pada arah yang benar seperti keimanan dan kebaikan, maka ia akan hanyut kepada ikatan dan kerinduan kepada dua hal tersebut, yang menjadikan terbentuknya akhlak yang mulia.

Strategi yang dapat diamaikan oleh orang tua pada saat itu ialah, menanamkan perkembangan keimanan kedalam diri anak dan memperkuat aqidahnya kepada Allah SWT yang akan ia lihat 
sebagai pertolongan terbaik dalam menghadapi realitas yang menyakitkan dan pergulatan kehidupan yang menyesakkan. Selain itu mengajak anak dalam memperdalam keimanan dengan cara untuk menyuruhnya melihat, berpikir dan merenungkan apa yang telah diciptakan-Nya. Melihat, berpikir dan merenungkan merupakan cara-cara yang Qur'ani yang melahirkan sikap menerima pengajaran, dan pengalaman, memperkuat keimanan, mendidik dan menjernihkan ruh, serta menghilangkan faktor-faktor kebodohan dan kelemahan yang berkaitan dengan ruh.

Menanamkan Rasa Kebanggan Beraga Islam di Dalam Diri Anak

Banyak anak-anak yang semakin bertambah usia dan hari, tanpa mengerti tujuan penciptaannya, bahkan masa bodo dengan misi penciptaannya, akibat pendidikan yang hanya berkutat pada persoalan yang remeh dan aspirasi-aspirasi yang rendah. Maka dari itu orang tua sebaiknya menanamkan rasa kebanggaan beragama Islam pada diri anak sejak kecil. Dia harus dididik berbeda dengan orang kafir dalam segala hal yaitu penampilan, tujuan dan citacitanya. Dia harus merasa bahwa dia berkaitan kepada umat yang mempunyai ikatan kepada Allah SWT, berjalan dengan petunjuk-petunjuk-Nya dan memiliki sesuatu yang tidak dimiliki umat lainnya yaitu Alquran, jalan Allah SWT, cahaya-Nya dan sunnah Rasul. Maka dari itu tugas orang tua yaitu menumbuhkan cakrawala kehiduapan anak, membukakan matanya akan penyakit yang diderita umat, mempersiapkan dirinya secara psikologis untuk menjalankan fungsinya, serta memberinya pembekalan untuk menggunakan waktu kosong. Caranya adalah dengan menanamkan rasa memiliki terhadap islam di dalam hatinya.

Mendidik Anak Untuk Beribadah Kepada Allah SWT, Melaksanakan Segala Syiar Islam, dan AmalAmal Sunnah

Mendidik anak untuk beribadah kepada Allah SWT sebiknya dimulai dengan teori dan praktik secara bersamaan. Hal itu dapat dilakukan dengan memberikan semangat dan dorongan, tanpa menggunakan cara-cara kekerasan, pemaksaan dan otot. Anak sebaiknya tidak huru-buru dihukum ketika tidak melaksnakan sebagian ibadah, karena ia belum terkena perintah (belum baligh) untuk menjalankan kewajiban-kewajiban agama. Dia hanya perlu dibiasakan untuk melaksanakn ibadah secara perlahan-lahan sampai ia terbiasa melakukannya dan tumbuhn sebagai anak yang rajib beribadah. Sehingga pada akhirnya ia pun tidak sulit melaksnaaknnya ketika nanti mencapai usia baligh.

Pembiasaan beribadah itu memang tidak akan terjadi dengan mudah, melaikan membutuhkan usaha keras. Namun setelah terjadi, maka akan menjadi hal yang mudah dan dapat dilakukan menjadi sangat ringan, tanpa merasa keberatan apa-apa. Menempa kebiasan sejak kecil jelas lebih mudah daripada ketika ia sudah dewasa. mengingat kemudahan pembentukan itu, Rasullah SWA memerintahkan orang tua muslim untuk membiasakan anak-anak mereka dengan salat sebelum jatuh masa (baligh) ketika besar nanti. Ketika setelah tiba masnaya, shalat pun akan menjadi rutinitas yang telah biasa dilakukananya.

Mendidik Keimanan Anak Mulai Dari Cara Makan, Minum dan Lain Sebagainya

Orang tua seyogianya mendidik anaknya agar meniatkan makanan dan minumannya demi menambah energi agar mampu melaksnakan ketaan kepada Allah SWT, sehingga dengan makan dan minum ia dapat menjadi orang yang taat dan tidak sekadar mengecap kenikmatan semata. Orang tua perlu menjelaskan keburukan prilaku makan yang berlebihan kepada anak mereka dan memikatnya agar puas menerima makanan yang ada. Allah SWT berfirman:

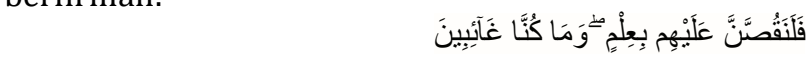
"makan dan minumlah, dan jangan berlebih-lebihan." (QS. Al-Araf (7): 31)

Selaian itu anak hendaknya dibiasakan membaca bismillah ketika hendak memulai makan, minum dan memulai segala pekerjaan, sebab hal itu adalah ajaran Nabi. Orang tua lah yang dianjurkan untuk menjadi teladan dalam hal itu. Kebiasaan yang perlu diajarkan dan dibiasakan kepada anak-anak sejak dini adalah:

a) Makan dan minum dengan tangan kanan.

b) Tidak memulai makan dari tengah-tengah (piring).

c) Menjilati jari-jari bekas makan dan tidak terburu mencuci tanganya sebelum menjilatiya.

d) Makan sampai bersih.

e) Membaca hamdalah usai makan dan minum.

Ketika orang tua menggunakan cara tersebut dan menempuh prinsip-prinsip diatas dalam mendidik anak merela, maka mereka berarti telah berperan dalam membentuk generasi muslim yang beriman kepada Allah SWT dan merasa bangga dengan agamanya. Ketika anak-anak sudah dibentuk dan tumbuh dalam penempaan keimanan kepada Allah, dididik untuk takut kepada-Nya, merasa diawasi-Nya, bersandar kepada-Nya, meminta pertolongan kepada-Nya dan patuh terhadap segala perintah-Nya maka akan berkembanglah bakat-bakat fitrahnya beserta reaksi otomatis untuk menerima kemuliaan, serta terbiasa berprilaku dengan akhlakul karimah. (Hannan, 2007: 1-53)

\section{Pendidikan Budi Pekerti Pada Anak}

Pendidikan budi pekerti merupakan nilai, pihak pertama yang paling cocok memberikan pendidikan budi perkerti adalah kelaurga. Pendidikan dapat dikelompokan menjadi tiga jenis, yaitu pendidikan informal, pendidikan formal, dan pendidikan nonformal. pendidikan formal bisannya sangat terbatas dalam memberikan pendidikan nilai. 
Hal ini disebabkan oleh maslaah formalitas hubungan antara guru dan siswa. Pendidikan nonformal dalam perkembangannya saat ini tampakya juga sangat sulit untuk memberikan perhatian besar pada pendidikan nilai. Hal ini berhubungan dengan proses transformasi budaya yang sedang terjadi dalam masyarakat kita.

Pembentukan karakter harus dilakukan secra sistematis dan berkesinambungan yang melibatkan aspek "knowledge, feeling, loving dan action. Pembentukan karakter dapat diibaratkan sebagai pembentukan seseorang menjadi body builder (binaragawan) yang memerlukan latihanlatihan otot-otot ahklak secara terus menerus agar menjadi kokoh.

Pada dasarnya anak yang kualitas karakternya rendah adalah anak yang tingkat perkembangan emosi-sosialnya rendah sehingga anak beresiko besar mengalami kesulitan belajar, berinteraksi sosial, dan tidak mampu mengontrol diri. Mengingat pentingnya penanaman karakter diusia dini dan. (Masnur, 2011: 200-202)

Pendidikan karakter sungguh sangat dibutuhkan dan diharapkan setiap orang tua memberikan pendidikan karakter. Pendidikan karakter ini tak hanya dari orang tua, pendidikan karakter ini pun bisa didapatkan dari keluarga, sekolah, dan masyarakat yang terkontribusi dengan baik. Semua komponen ini harus bersinergi dalam pembentukan karakter yang baik pada anak. Dalam lingkungan yang baik anak akan menjadi pribadi yang baik pula, sebaliknya jika lingkungan orang tua, keluarga dan masyarakat tidak terkontribusi dengan baik maka anak pun akan mendapatkan karakter yang kurang baik. Lingkungan yang baik ini snagat sulit untuk di dapatkan dilihat dari daerah kita yang bersuku-suku, berbangsa, dan berbudaya yang berbeda antara satu dan lainya menjadikan ketidak singkronan diantara satu dan lainnya.

Kecerdasan emosi kini jadi peratian dan prioritas. Kecerdasan emosi ialah bekal terpenting dalam mempersiapkan anak dalam menyongsong masa depan karena degannya seseorang akan dapat berhasil dalam menghadapi segala macam tantangan. Kecerdasan emosi juga sangat penting dalam hubungan pola suh anak dengan orang tua. Hasil studi Dr. Marvin Berkowitz dari University of Missouri St. Lauis, yang diterbitkan dalam sebuah buletin. Dalam penelitian tersebut dijelas tentang peningkatan motivasi siwa sekolah dalam meraih prestasi akademik pada sekolah-sekolah yang menerapkan pendidikan karakter.

Anak-anak yang mempunyai masalah dalam kecerdasan emosinya, akan mengalami kesulitan belajr, bergaul dan tidak dapat mengotrol emosinya. Anak-anak yang bermasalah ini dapt dilihat pada usia prasekolah, dan jika tidak ditangani akan terbawa samapai dewasa. sebaliknya jika pada remaja yang mempunyai karakter atau kecerdasan emosi tinggi akn terhindar dari maslah-masalh umum yang dihadapi oleh remaja seperti kenakalan, tauran, narkoba, miras, prilaku seks bebas dan sebaginya. pendidikan karakterdi sekolah snaagt diperlukan walaupu dasar dari pendidikan karakter adalah di dalam keluarga. Jika seorang anak mendapatkan pendidikan karakter yang baik dari keluarganya, anak tersebutakan berkarakter baik selanjutnya. (Masnur, 2011: 151-152)

Maka dari itu, orang tua dan keluargamenjadi peran utama yang akan mendukung kecerdasan emosi anaknya. Orang tua yang medidik anak sejak kecil harus menanamkan pelajaran tentang kecerdasan emosi atau pendiikankarakter, dengan dibantu oleh keluarga yang juga akan memberikan pendidikan karakter yang ercipta dari diri anak sejak dini. Tak hanya dari sisi orang tua dan keluarga, namun kecerdasan emosi atau pendidikan karakter ini pun dapat diperoleh dai seolah dan juga masyarakat. Maka, orang tua harus cermat memilih pendidikan dan mendampingi anak dalam setiap perkembangannya.

\section{Nilai-nilai Pendidikan Agama Islam}

Nilai-nilai agama islam memuat aturanaturan Allah yang antara lain meliputi aturan yang menghubungkan tentang hubungan amusia dengan Allah, hubungan manusia dengan manusia, dan hbungan manusia dengan alam secara keseluruhan. Manusia akan mengalami ketidaknyamanan, ketidak-harmonisan, ketidaktentraman, atau pun mengalami permasalahan dalam hidupnya, jika dalam mengalami hubunganhubungan tersebut terjadi ketimpangan atau tidak mengikuti aturan yang telah ditetapkan oleh Allah. (Hakim 2012: 69).

Aspek nilai-nilai agama islam pada initinya dapat dibedakan menjadi tiga jenis yaitu, nilai-nilai aqidah, nilai-nilai ibadah, dan nilai-nilai akhlak. Nilai-nilai aqidah mengajarkan manusia untuk percaya akan adanya Allah Ynag Maha Esa dan Maha Kuasa sebagai Sang Pencipta Alam Semesta yang akan senantiasa mengawasi dan memperhitungkan segala perbuatan manusia di dunia. Dengan merasa sepenuh hati bahwa Allah itu ada dan Maha Kuasa, maka manusia akan lebih taat dalam menjalankan sesuatu yang telah diperintahkan oleh Allah dan takut untuk berbuat dhalim atau kerusakan dimuka bumi ini. Nilai-nilai ibadah mengajarkan pada setiap manusia agar dalam setiap perbuatannya senantiasa dilandasi hati yang ikhlas guna mendapatkan ridho Allah. Pengamalan konsep nilai-nilai ibadah akan melahirkan manusia-manusia yang adil, jujur, dan suka membantu sesamanya. Selanjunya yang terakhir nilai-nilai ahklak mengajarkan pada manusia unatuk bersikap dan berprilaku yang baik sesuai norma atau adab yang benar dan baik, sehingga akan membawa kehidupan manusia yang 
tentram, damai, harmonis dan seimbang. Dengan demikian jelas bahwa nilai-nilai ajaran agama islam merupakan nilai-nilai yang akan mampu membawa manusia kepada kebahagiaan, kesejahteraan, dan keselamatan manusia baik dalam kehidupan manusia di dunia maupun kehidupan di akhirat kelak.

Nilai-nilai agama islam memuat aturanaturan Allah yang antara lain meliputi aturan yang menghubungkan tentang hubungan amusia dengan Allah, hubungan manusia dengan manusia, dan hbungan manusia dengan alam secara keseluruhan. Manusia akan mengalami ketidaknyamanan, ketidak-harmonisan, ketidaktentraman, atau pun mengalami permasalahan dalam hidupnya, jika dalam mengalami hubunganhubungan tersebut terjadi ketimpangan atau tidak mengikuti aturan yang telah ditetapkan oleh Allah. (Hakim 2012: 69).

Pendidikan menurut islam ialah keseluruhan pengertian yang terkandung dalam istilah ta'lim, tarbiyyah dan ta'dib. Menurut Naquib al-Attas istilah ta'dib adalah istilah yang paling tepat diunakan untuk menggambarkan pengertian pendidikan, sedangkan istilah tarbiyyah terlalu luas karena pendidikan adalm islam ini mecakup juga pendidikan hewan. Pendidikan menurut islam ialah usaha agar orang mengenali dan mengakui tempat Tuhan dalam kehidupan ini. Akan tetapi, Abdurrahman al-Nahlawi merumuskan defini pendidikan dari kata tarbiyyah menurut dari segi bahasa tarbiyyah berasal dari tiga kata, berdasarkan dari tiga kata itu pendidikan terdiri atas empat unsur yaitu menjaga dan memelihara fitrah anak sebelum dewasa, mengembangkan seluruh potensi, mengarahkan seluruh fitrah dan potensi, dan dilaksanakn secara bertahap. Disini dapat disimpulkan bahwa pendidikan adalah pengembangan seluruh potensi anak didik secara bertahap menurut ajaran islam. (Ahmad, 2007: 29)

Empat unsur yang menjaga dan mempelihara fitrah anak, menurut Mohammad Roesli, Ahmad Syafi'i dan Aina Amalia. (2018: 338339) ialah, materi pendidikan yang disajikan minimal meliputi tarbiyah rohaniyah, tarbiyah adabiyah, tarbiyah aqliyah, tarbiyah jismiyah. Untuk itu di sini akan dijelaskan dalil naqli dari materi pendidikan tersebut, sebagai berikut:

a. Tarbiyah Rohaniah

Firman Allah SWT dalam surat Lukman ayat 12 dan 13 :

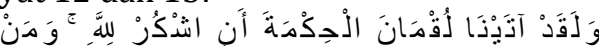

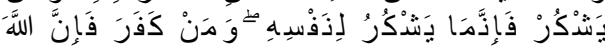

$$
\begin{aligned}
& \text { غَذَِيٌّ حَمِيدُ }
\end{aligned}
$$

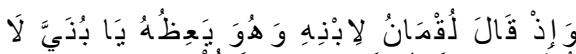

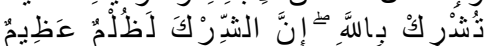

Artinya: "Sesungguhnya kami telah memberikan hikmah (kebijaksanaan) kepada Luqman : Syukurlah kepada Allah, siapa yang bersyukur sesungguhnya dia bersyukur untuk (kebaikan) dirinya sendiri, dan siapa yang menyangkal (tidak bersyukur), sesungguhnya Allah itu Maha kaya dan terpuji (Q.S. 31 : 12)

"Dan (ingatlah)ketika Luqman berkata kepada anaknya dan dan dia mengajarkan : "Hai anakku janganlah kau mempersekutukan Allah, sesungguhnya mempersekutukan Allah itu adalah kesalahan yang besar". (Q.S. 31 : 13)

Dari kedua ayat tersebut, menyatakan bahwa kita senantiasa harus selalu bersyukur atas apapun yang telah Allah berikan, sesungguhnya Allah itu Maha kaya dan terpuji. Sementara itu, janganlah kamu menyekutukan Allah dengan yang lain, karena sesungguhnya menyekutukan Allah adalah suatu kezaliman yang besar. Sebab dalam hal ini terdapat persamaan antara yang berhak dan yang tidak berhak untuk di sembah. Maka dari itu, orang tua senantiasa selalu memberikan pendidikan perinsip ini kepada anak-anak nya sedari kecil.

b. Tarbiyah Adabiyah

Tarbiyah Adabiyah ialah akhlak untuk berbakti kepada kedua orang tua. Kita harus selalu berbakti kepada kedua orang tua kita, karena merekalah yang selalu ada, merawat dan mengurus kita dari kecil hingga dewasa, yang telah banyak berkorban bagi kelangsungan hidup anak-anaknya.

Firman Allah SWT dalam surat Luqman ayat14 :

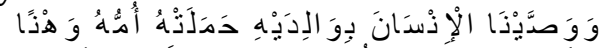

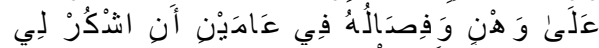

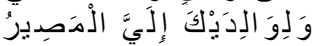

Artinya :"Dan kami wasiatkan (perintahkan) kepada manusia (supaya) berbuat baik kepada ibu bapaknya. Ibunya mengandung dengan menderita kelemahan di atas kelemahan dan menceraikan menyusu dalam dua tahun. Bersyukurlah kepadaKu dan kepada ibu bapakmu kepada Ku tempat kembali" (Q.S. 31:14)

\section{c. Tarbiyah Aqliyah}

Tarbiyah Aqliyah ialah pendidikan mengenai akhlak dalam mencari ilmu, sebagai manusia yang telah dianugrahi akal, maka kita berkewajiban untuk mencari ilmu agar mendapatan ilmu pengetahuan.

Firman Allah di dalam Surat Ali Imron ayat 190 :

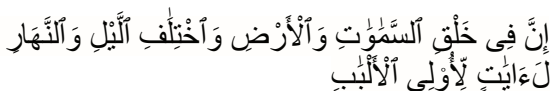

Artinya: "Sesunguhnya tentang kejadian langit dan bumi dan pergantian malam dan siang akan menjadi keterangan bagi orang-orang yang mengerti" (Q.S. 3:190) 
Jurnal Edumaspul, 5 (2), Year 2021- 542

(Ani Muflikah, , E. Tajuddin Noor, Taufik Mustofa)

d. Tarbiyah Jismiyah

Tarbiyah jismiah ialah akhlak terhadap diri sediri, Allah akan memberikan kenikmatankenikmatan bagi hambanya yang mematuhi perintahnya dan menjauhi larangannya.

Firman Allah SWT dalam surat Al Baqarah 247 yang berbunyi:

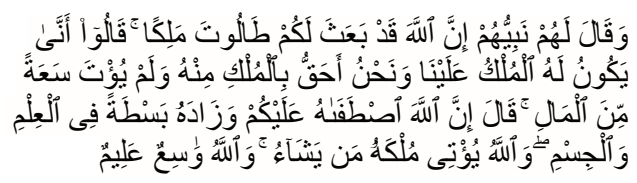

Artinya: "Dan nabinya mengatakan kepada mereka : Sesungguhnya telah menetapkan Thalut menjadi rajamu. Mereka mengataka: Bagaimana Thalut dapat berkuasa atas kami, sedang kami lebih berhak dengan kekuasaan itu dari padanya, dan dia tidak mempunyai kekayaan yang cukup? Kata nabi-Nya Sesungguhnya Allah lebih 340 memilikinya menjadi raja untuk kamu dan akan dianugerahi-Nya lagi kepadanya ilmu yang luas dan badan yang kuat. Allah memberikan kerajaan kepada siapa yang disukai-Nya, dan Allah itu luas pemberian-Nya dan Maha Tahu" (QS. 2:27)

Pendidikan keimanan termasuk salah satu jenis pendidikan terpenting yang mempunyai pengaruh yang sangat besar dalam kepribadian seseorang yang mebuatya menjadi orang yang cenderung kepada kebaikan, menghias diri dengan sifat-sifat terpuji dan selalu membiasakan diri dengan akhlakul karimah. Pendidikan keimanan menjadi kewajiban orang tua terhadap anak-anak mereka dalam setiap fase pertumbuhan anak, tentusaja dengan memperhatikan metodologi pelaksanaanya. (Hannan, 2013: 2-3)

Pendidikan keimanan adalah sinergi berbagai unsur aktivisan pedagogis: pengaitan anak-anak dengan dasar-dasar keimanan,pengakrabannya dengan rukun-rukun islam, dan pembelajarannya tenang perinsip-prinsip syariat islam, pendidikan karakter dan insting anak yang tumbuh berkembang, pengarahan prilaku mereka sesuai dengan fondasi nilai, prinsip-prinsip, dan norma-norma etik yang bersumber dari keimanan yang benar kepada Allah SWT, malaikat, kitab-kitab, par rasul, hari alhir, dan qadha-Nya, yang baik ataupun buruk. (Hannan 2013: 1)

\section{Pembelajaran Jarak Jauh}

Pembelajaran jarak jauh adalah pembelajaran ketika siswa dan pengajar tidak selalu hadir secara fisik secra bersamaan di sekolah. Pelaksanaan bisa sepenuhnya jarak jauh atau campuran jarak jauh dengan kelas. Pembelajaran jarak jauh pertama seperti saat ini dilakukan oleh Isac Pitnam pada tahun 1840an, yang mengajar sistem setno dengan mengirimkan beberapa teks yang ditranskripsi menjadi setno pada kartu pos dan menerima transkripsi dari siswa guna menerima umpan balik. Unsur umpan balik adalah inovasi penting dari Isac Pitman. Perkembangan penggunaan internet telah menjadikan pembelajaran jarak jauh lebih mudah dan cepat, bahkan pada saat ini sekolah dan universitas virtual memberikan kurikulum daring penuh. Di Indonesia universitas yang memberikan fasilitas pembelajran jarak jauh ialah program pasca sarjana pendidikan IPA Universitas PGRI Senarang. (Rifki, 2020:2).

Pelaksanaan distance learning membutuhkan komunikasi yang baik antara siswa, orang tua, dan sekolah dikarenakan jarak yang jauh dan tidak memungkinkan antara siswa, orang tua, dengan sekolah bisa bertemu muka secara terus-menerus. komunikasi antara siswa dengan sekolah dilakukan secara virtual atau dunia maya. Media yang digunakan adalah beberapa media sosial yaitu: Facebook, WhatsApp, dan Skype. Sedangkan antara orang tua dengan sekolah lebih banyak kepada konsultasi, diskusi, maupun sharing mengenai perkembangan belajar anak selama mengikuti distance learning dan kelanjutan pendidikan siswa setelah lulus nanti juga dikonsultasikan kepada sekolah.

Dalam proses berlangsungnya pembelajaran jarak jauh ini, tidak hanya menguatkan sistem guru dan murid saja. Namun pada saat pembelajaran jarak jauh ini ada andil orang tua yang menjadi peran penting saat proses pembelajaran berlangsung. Dengan adanya bimbingan orang tua yang ketak dan tepat terhadap anaknya, maka akan menghasilkan pembelajaran jarak jauh yang berhasil.

Dimasa pandemi Covid-19 pendidik seperti guru dituntut harus memahami semua metoda ataupun tata cara dalam pelaksanaan pengajaran dalam bentuk onlinepada proses pembelajaran Jarak Jauh (PJJ). Tenaga pendidik tersebut memiliki tugas pokok kerja meliputi sebagai tenaga pengajar bagi siswa, sebagai orang yang bertanggung jawab dalam pemberian materi dan melaksanakan tugas lain yang ditugaskan oleh pemerintah. Guru di sekolah melakukan dua tuga pokok yanitu memberikan perencanaan dan memberikan penilaian hasil yang dicapai oleh siswa selama melakukan proses pembelajaran Sehingga sangat diharapkan guru mampu memberikan metode pembelajaran yang cocok selama masa pandemi. Sedangkan murid merupakan objek penerimaan dalam pelaksanaan Pembelajaran Jarak Jauh (PJJ). Murid akan menerima dan menerapkan langsung metode ataupun model pembelajaran apa saja yang diberikan atau disampaikan.

Dalam metode belajar yang sudah mulai diterapkan dengan sistem PJJ tentu akan mempengaruhi bagaimana aspek penerimaan dari murid. Murid juga diharapkan memiliki kesadaran bahwa kegiatan pembelajaran dirumah merupakan suatu kewajiban yang harus dilaksanakan. Peran dan tugas tanggungjawab orang tua juga sangat penting. Disisi lain kecemasan, 
sedih, bosan yang dirasakan oleh peserta didik pasti akan muncul, sehingga orangtua diharapkan mampu memberikan penguatan secara internal terhadap peserta didik. (Sri, 2020: 6)

Kelebihan pembelajaran jarak jauha antara lain, dapat memperluas akses pendidikan untuk masyarakat umum dan bisnis karena stuktur penjadwalan yang fleksibel mengurangi dari efek kendala waktu dan tepat, penyerahan beberapa kegiatan di luar lokasi mengurangi kendala kapasitas kelembagaan yang timbul dari kebutuhan bangunan imfrakstuktur, serta terdapat potensi untuk meningkatkan akseks ke lebih banyak pakar dari berbagai latar belakang geografis, sosial, budaya, ekonomi, dan pengalaman. Namun pemelajaran jarak jauh juga memiliki kekurangan yaitu, hambatan untuk pembelajaran efektif seperti ganguan rumah tangga dan teknologi yang tidak dapat diandalkan, interaksi yang tidak memadai antara iswa dan pengajar, serta kebutuhan untuk pengalaman yang lebih banyak. (Rifki, 2020:2).

Dari beberapa pengamatan mengenai proses pembelajaran secara jarak jauh/ daring juga ditemukan beberapa masalah, seperti aspek kendala implementasi program pembelajaran jarak jauh yaitu aspek pedagogi, teknologi dan ekonomi. Dari segi pedagogi tidak semua proses pelaksanaan pembelajaran online sukses dilaksanakan, karena keterbatasan faktor lingkungan belajar dan juga karakteristik peserta didik. Kemudian Dari aspek teknologi tidak semua pengajar dan peserta didik bisa menggunakan aplikasi langsung dan pandai dengan perangkat leptop atupun hadphone, dari aspek ekonomi sangat diperlukan perangkat pendukung sepertileptop ataupun smart phone untuk terhubung diinternet dan masalah lainnya seperti kurangnya minat belajar siswa karena perubahan suasana belajar dan lainnya.

\section{Simpulan}

Peranan orang tua dalam penerapan nilai-nilai pendidikan agama islam sangatlah penting sebagai proses pembentukan karakter, pribadi anak yang baik, berbudi pekerti luhur, normatif, agamis serta berakhlakul karimah sehingga dapat bersikap dan berbuat sesuai dengan ketetapan agama. Apalagi pada masa pandemi covid-19 yang sedang terjadi hingga hari ini, mengharuskan orang tua mempunyai peranan ganda dalam mendidik anak-anaknya, agar tercapai segala suat tujuan dari pembelajaran.

\section{Daftar Pustaka}

[1] Ahmad, A. U. F., \& Hassan, M. K. (2007). Regulation and performance of Islamic banking in Bangladesh. Thunderbird International Business Review, 49(2), 251277.
[2] ALI FATHONI, M. N. A. F. (2018). THE ESTABLISMENT OF THE STUDENT'S SPIRITUAL ATTITUDE BASED ON AL ISLAM AND KEMUHAMMADIYAHAN AT VOCATIONAL HIGH SCHOOL OF MUHAMMADIYAH 1 (SMKM1) KEPANJEN (Doctoral dissertation, Universitas Muhammadiyah Malang).

[3] Elihami, E., \& Syahid, A. (2018). Penerapan Pembelajaran Pendidikan Agama Islam Dalam Membentuk Karakter Pribadi Yang Islami. Edumaspul: Jurnal Pendidikan, 2(1), 79-96.

[4] Hakim, L. (2012). Prinsip-prinsip ekonomi islam. Jakarta: Erlangga.

[5] Hasnidar, H., \& Elihami, E. (2019). The management Model of National Character Education for Early Childhood Education through based on Democracy. Edumaspul: Jurnal

[6] Muslich, M. (2008). Kekuasaan Media Massa Mengonstruksi Realitas. Jurnal Bahasa dan Seni, 36(2), 150-159.

[7] Nasution, S. (1998). Didaktik azaz-azaz mengajar. Bandung: Jemmars.

[8] Pendidikan, 3(1), 15-19.

[9] Setiawan, A. R. (2020). Lembar kegiatan literasi saintifik untuk pembelajaran jarak jauh topik penyakit coronavirus 2019 (COVID-19). Edukatif: Jurnal IImu Pendidikan, 2(1), 28-37.

[10] Usman, M. U. (2006). Menjadi guru profesional. 